\title{
Isolation and identification of biologically active components from the honey bee venom apis mellifera I. caucasica
}

\begin{abstract}
The article presents experimental data on the separation and identification of biologically active components of the venom of the honey bee Apis mellifera L. Caucasica. By gel chromatography on a column with Servacel-52 eluting with a linear gradient of $\mathrm{NaCl}$ concentration from 0.01 to $1 \mathrm{M}$, followed by spectrophotometric measurement of the unit of optical density at an absorption wavelength of $\lambda=280 \mathrm{~nm}$ on a Hitachi-557 spectrophotometer from the honey bee venom, biologically active components of zootoxin with molecular weights of 12000, 14600 and 22000D. A polypeptide with $\mathrm{Mg} \sim 12000 \mathrm{D}$ is a toxic component identified as mellitine, a polypeptide with $\mathrm{Mg} \sim 14600$ is an enzyme of phospholipase A2, and a polypeptide with $\mathrm{Mg} 22000 \mathrm{D}$ is a glycoprotein.
\end{abstract}

Keywords: venom, honey bee, apis mellifera 1. caucasica, spectrophotometer, peptides, enzymes
Volume 3 Issue 7 - 2017

\author{
Mammadova FZ, Topchiyeva ShA \\ Institute of Zoology of NAS of Azerbaijan, Azerbaijan
}

Correspondence: Topchiyeva ShA, Institute of Zoology of NAS of Azerbaijan, Baku, AZI 073, Baku, Sabail, Abbasgulu Abbaszadeh, II5,Azerbaijan, Email shafiga.topchiyeva@mail.ru

Received: December I I, 20I7 | Published: December 19, 2017

\section{Abbreviations: PLA, phospholipase; HYA, hyaluronidase}

\section{Introduction}

The venom of the European honey bee Apis mellifera is an intricate mixture of chemical compositions, including proteins, peptides, enzymes, and other small molecules. Lately, there has been growing interest in the use of melittin, due to its wide range of biological and potential therapeutic applications. Melittin, which is considered to be an antimicrobial, antitumor, and anti-inflammatory peptide, is the main component $(\geq 50 \%(\mathrm{w} / \mathrm{w}))$ of honey bee venom and is widely used in oriental medicine ${ }^{1}$ and studied as an alternative for treating drug-resistant infections..$^{2-4}$ In parallel to antimicrobial peptides for therapeutic use in humans, melittin can be used to fight economically important plant pathogens that limit crop production globally. ${ }^{5}$ Phospholipase A2 (PLA2) and hyaluronidase (HYA) are the two major enzymatic proteins present in the bee venom. ${ }^{6,7}$ Both of these enzymes are classified as major allergens according to the International Union of Immunological Societies, as they are capable of inducing the IgE response in susceptible individuals..$^{6-8}$

The results of study confirm that a high purity and recovery yield of melittin can be obtained with a one-step purification method with strong cationexchange chromatography resins using sodium phosphate buffer at $\mathrm{pH}$ 6. The optimal step-wise elution condition was designed to increase the yield and concentration of the melittin collected. An increased mass of crude bee venom for purification of melittin was also made possible with the optimal condition used in this study. Study has proved to solve the problem whereby melittin can be highly recovered with its allergenic contaminants such as PLA2 and HYA removed in a single-step purification The concern over the use of melittin in honey bee venom due to its adverse reaction caused by allergens such as phospholipase A2 (PLA2) and hyaluronidase (HYA) has been an obstacle towards its usage. Authors developed a novel single-step method for melittin purification and the removal of PLA2 and HYA. This study explores the influence of $\mathrm{pH}$, buffer compositions, salt concentration, and types of cation-exchange chromatography resins on the recovery of melittin and the removal of both HYA and PLA2. Melittin was readily purified with a strong cation-exchange resin at $\mathrm{pH} 6.0$ with sodium phosphate buffer. It resulted in a recovery yield of melittin up to $93 \%$ (5.87 $\mathrm{mg}$ from a total of $6.32 \mathrm{mg}$ of initial melittin in crude bee venom), which is higher than any previously reported studies on melittin purification. PLA2 (99\%) and HYA $(96 \%)$ were also successfully removed. Melittin with a high removal rate of PLA2 and HYA, enabling to be fully utilized for its therapeutic purposes. ${ }^{9}$

Mellitin is the main cytolytic linear peptide with a molecular weight of $2.8 \mathrm{kDa}$ (26 amino acid residues), isolated from the honey bee venom and possessing the properties of a surfactant. Melittin causes hemolysis of erythrocytes, releases histamine from mast cells. The peptide also increases the fluidity of the phospholipid matrix of the membranes, which leads to a change in the activity of many membrane-bound enzymes. The physicochemical properties of melitin cause its pronounced antibacterial activity against many species of microorganisms, including mycoplasma. Phospholipase A2 (FLA2) is a calcium-dependent enzyme. The enzyme has a molecular weight of 14629Da and consists of 129 amino acid residues, of which 12 are cysteine, which enter the disulfide bridges. It is capable of hydrolyzing phospholipids, resulting in the formation of lysolecithin, which has a cytolytic effect. It has the ability to lyse membranes of many cells (erythrocytes, mast cells), thereby providing a manifestation of pathological effects. In the presence of melitin, the phospholipase becomes more active and toxic. It is suggested that melitin prepares phospholipids for enzymatic activity of phospholipase by its reduced surface tension. Of all the components of bee venom, phospholipase is the strongest antigenic and allergenic protein. Melitin has a hemolytic, antiviral, antifungal and cytolytic effect, causing the death of cells and their organelles. In view of the high cytotoxic and hemolytic activity of melitin, work is underway for its practical use in oncology. ${ }^{10}$

Like other components of the bee venom: hyaluronidases, 
apamines, acid phosphatases, etc., melitin also causes degranulation of mast cells and cytotoxicity. Unlike melitin, FLA2 causes only degranulation, cytotoxic effects. Bites of bees can cause lifethreatening, and sometimes lethal, antigen-dependent anaphylactic reactions in the human body. ${ }^{11}$ See venom contains specific protease. It consists about $0.8-15 \%$ of total proteine-peptide fraction. The enzyme was purified with the help of benzamedine-sepharose and reverse-fase chromatography to the activity $110 \mathrm{U} / \mathrm{mg}$. The protein is hydrophobic, its $\mathrm{Mr}$ is equal to $20 \mathrm{kDa}$ (by gel-filtration), pHopt 4.5 . Protease specifically binds to cell membrane in cooperative manner; the maximal binding ratio is 1.2. Enzyme has high substrate specifity for membrane proteins. It is concluded that protease is a specific toxic component of bee venom. ${ }^{12}$ The molar mass of mellitine is 2840 , but the molecular weight determined by analytical ultracentrifugation is 12 , 500 , which agrees with the tetrameric form in a concentrated aqueous solution of high ionic strength (conditions used for ultracentrifugation). The molar mass of melittin is 2840 but the molecular weight, determined by analytical ultracentrifugation, is 12,500 , which is consistent with a tetrameric form in concentrated aqueous solution at high ionic strength, (the conditions used for ultracentrifugation). The peptide acts synergistically with phospholipase A2 on phospholipid structures, whether of natural membranes or liposomes. Although considerably smaller than phospholipase A2 (molar mass 17,500), separation of the peptide (about $40-50 \% \mathrm{w} / \mathrm{w}$ of bee venom) from the enzyme is complicated by the tendency of the peptide to aggregate. ${ }^{13}$ In connection with the foregoing, there is a need to isolate the biologically active components of the venom of the honey bee, followed by a study of physicochemical properties and biological activity. The aim of the research was the separation, isolation and identification of the main biologically active components of the venom of the honey bee Apis mellifera L. Caucasica.

\section{Materials and results of the study}

The material of the studies was the whole poison of the honey bee Apis mellifera L. Caucasica. To separate the bee venom components, an ion-exchange chromatography method was used in glass chromatographic columns. Servacel DEAE-52 (Budapest, Hungary) was used as the adsorbent. To construct the calibration curve, the following marker proteins were used: cytochrome $\mathrm{C}(\mathrm{Mz}$ $12 \mathrm{kD})$, trypsin $(20 \mathrm{kD})$, erythrocyte spacecraft $(30 \mathrm{kD})$, and albumin lyophilized from human serum $(67 \mathrm{kD})$. One division was started by 4 proteins, $2 \mathrm{mg}$ each the fractions were collected in $3 \mathrm{ml}$ and the optical density was measured on a spectrophotometer. The spectrophotometric determination data are presented in Table 1 and in Figure 1.

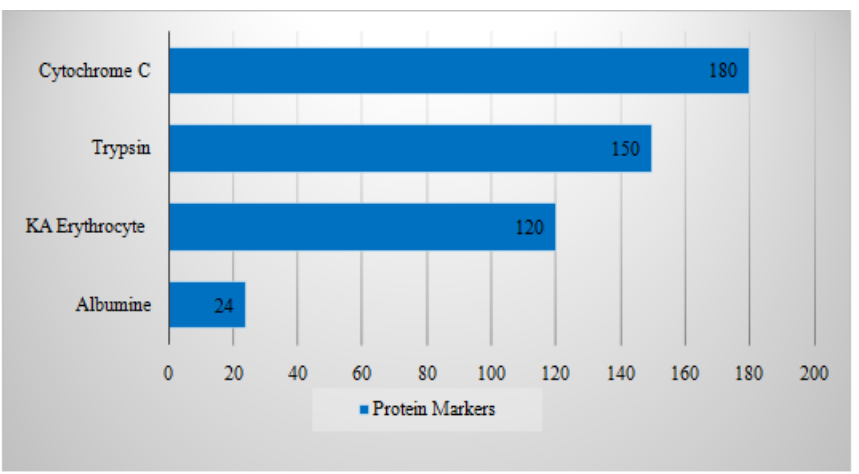

Figure I Diogramme of optical density of bee venom fractions, separated by ion exchange chromatography on a column with Servacel-52.
Table I The separation of marker proteins by gel filtration on a column with Servacel 52

\begin{tabular}{llll}
\hline No. of fractions & Protein markers & VR, MI & MM, Kda \\
\hline I & Albumine & 24 & 67 \\
2 & KA Erythrocyte & 120 & 30 \\
3 & Trypsin & 150 & 20.1 \\
4 & Cytochrome C & 180 & 12 \\
\hline
\end{tabular}

In a subsequent stage of the study, the dried crude bee venom (40mg) was dissolved in $2.0 \mathrm{ml}$ of water. Since the bee venom readily dissolves in water and the insoluble foreign matter remains undissolved, for a preliminary purification this poison solution is centrifuged at $6,000 \mathrm{rpm}$ for $15 \mathrm{~min}$ at $4^{\circ} \mathrm{C}$. The supernatant was then separated, followed by filtration, passing the solution through a glass filter with a pore size of $0.20 \mu \mathrm{m}$ and $0.45 \mu \mathrm{m}$ (Millipore, USA). The poison solution was prepared immediately before separation. To separate the components of the poison, the resulting solution in a volume of $1 \mathrm{ml}$ was mixed with an equal volume of $1 \mathrm{ml}$ of buffer to a total volume of $2 \mathrm{ml}$, and layered on a Servacel-52 column. Samples were chromatographed at room temperature at a flow rate of $3 \mathrm{ml} / \mathrm{min}$. Once the sample was loaded onto the column, the column was washed with a buffer solution to remove unbound samples. Elution was carried out using an elution buffer with a linear gradient of $\mathrm{NaCl}$ concentration of 0.01 to $1 \mathrm{M}$ to ensure effective elution of the components of the honey bee venom. The optical density of the fractions was measured on a Hitachi-557 spectrophotometer at an absorption wavelength at $\lambda=280 \mathrm{~nm}$. The fractions were collected in a volume of $3 \mathrm{ml}$ (Table 2). The separation of bee venom proteins by the ion-exchange chromatography-graphite method by stepwise elution in a concentration gradient of $0.01-1 \mathrm{M}$ sodium chloride solution is shown in Figure 2. The separation of bee venom proteins by gel chromatography on a column with Sephadex G-75 is shown in Table 3 \& Figure 3. Comparing the data obtained by us with data from literature sources, it can be stated that we identified and identified mellitine, glycoprotein and phospholipase A2 with molecular weights of $12,000,14,600$ and $22,000 \mathrm{D}$, respectively. ${ }^{15,16}$

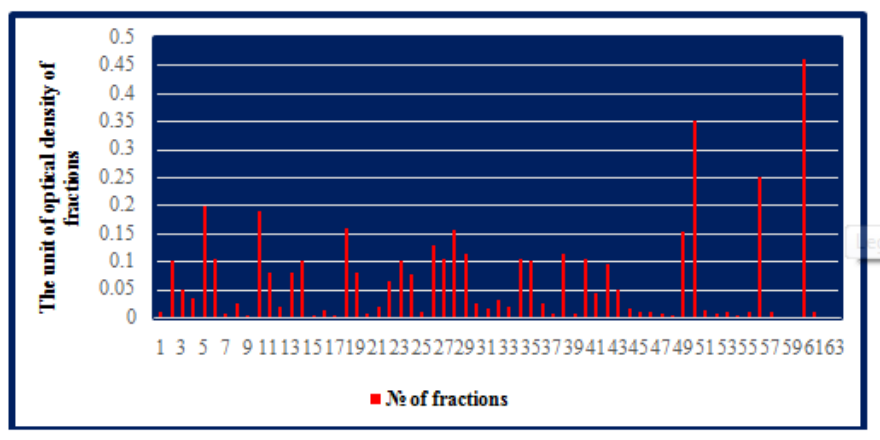

Figure 2 Diogramme of spectrophotometric separation of marker proteins, gel filtration on a column with Servacel 52.

From the above and on the basis of our experimental data, the eluent was selected and optimal conditions for separation and fractionation of the venom proteins were graded by stepwise elution with a concentration gradient of $0.01-1 \mathrm{M}$ sodium chloride solution on a Servacel-52 servacel column. Based on the results obtained, we believe that the ion exchange chromatography method can be 
used to separate the biologically active components of the honey bee venom. Thus, biologically active components of the poison with molecular weights of $12,000,14,600$ and $22,000 \mathrm{D}$ were isolated and identified. It should be noted that bee venom is a source for the production of biologically active peptides: melitin, apamin, adolapin, MSD-peptide, secapine, tertapine and enzymes: phospholipase A2, hyaluronidase. Mellitin, phospholipase A2 and glycoprotein, which exhibit antibacterial, antiviral and anti-inflammatory properties, are of particular interest among the biologically active components of honey bee venom. These components of the honey bee venom are more preferable alternatives to existing diagnostic and therapeutic drugs, since they have a faster activation rate, a lower probability of developing resistance reactions in the body, and the possibility of their use in combination with other drugs and preparations. At the same time, being a natural source for many drugs, in the near future, in combination with other biologically active components of natural origin, can become the basis for the development and production of promising and effective tools for the treatment and diagnosis of human diseases.

Table 2 Optical density of bee venom fractions, separated by ion exchange chromatography on a column with Servacel- 52

\begin{tabular}{|c|c|c|c|c|c|}
\hline $\begin{array}{l}\text { No. of } \\
\text { fractions }\end{array}$ & $\begin{array}{l}\text { The unit of optical } \\
\text { density of fractions }\end{array}$ & $\begin{array}{l}\text { No. of } \\
\text { fractions }\end{array}$ & $\begin{array}{l}\text { The unit of optical } \\
\text { density of fractions }\end{array}$ & $\begin{array}{l}\text { No. of } \\
\text { fractions }\end{array}$ & $\begin{array}{l}\text { The unit of optical } \\
\text { density of fractions }\end{array}$ \\
\hline I & 0.010 & 25 & 0.009 & 49 & 0.152 \\
\hline 2 & 0.101 & 26 & 0.128 & 50 & 0.350 \\
\hline 3 & 0.050 & 27 & 0.104 & 51 & 0.012 \\
\hline 4 & 0.035 & 28 & 0.155 & 52 & 0.006 \\
\hline 5 & 0.199 & 29 & 0.113 & 53 & 0.011 \\
\hline 6 & 0.104 & 30 & 0.025 & 54 & 0.004 \\
\hline 7 & 0.006 & 31 & 0.015 & 55 & 0.009 \\
\hline 8 & 0.026 & 32 & 0.030 & 56 & 0.250 \\
\hline 9 & 0.004 & 33 & 0.020 & 57 & 0.011 \\
\hline 10 & 0.190 & 34 & 0.105 & 58 & 0.002 \\
\hline II & 0.080 & 35 & 0.100 & 59 & 0.001 \\
\hline 12 & 0.020 & 36 & 0.024 & 60 & 0.460 \\
\hline 13 & 0.081 & 37 & 0.007 & 61 & 0.011 \\
\hline 14 & 0.100 & 38 & 0.115 & 62 & 0.002 \\
\hline 15 & 0.004 & 39 & 0.008 & 63 & 0.001 \\
\hline 16 & 0.129 & 40 & 0.105 & - & - \\
\hline 17 & 0.003 & 41 & 0.045 & - & - \\
\hline 18 & 0.158 & 42 & 0.095 & - & - \\
\hline 19 & 0.08 & 43 & 0.050 & - & - \\
\hline 20 & 0.007 & 44 & 0.016 & - & - \\
\hline 21 & 0.020 & 45 & 0.010 & - & - \\
\hline 22 & 0.065 & 46 & 0.009 & - & - \\
\hline 23 & 0.100 & 47 & 0.006 & - & - \\
\hline 24 & 0.077 & 48 & 0.004 & - & - \\
\hline
\end{tabular}


Table 3 Data for separation of bee venom components by gel chromatography on a column with Sephadex G-75

\begin{tabular}{llll}
\hline No. of fractions & $\begin{array}{l}\text { Components of } \\
\text { the bee venom }\end{array}$ & VR, MI & M M, Kda \\
\hline I & Glycoprotein & 150 & 22 \\
2 & Phospholipasa A2 & 170 & 14.6 \\
3 & Mellitine & 180 & 12 \\
\hline
\end{tabular}

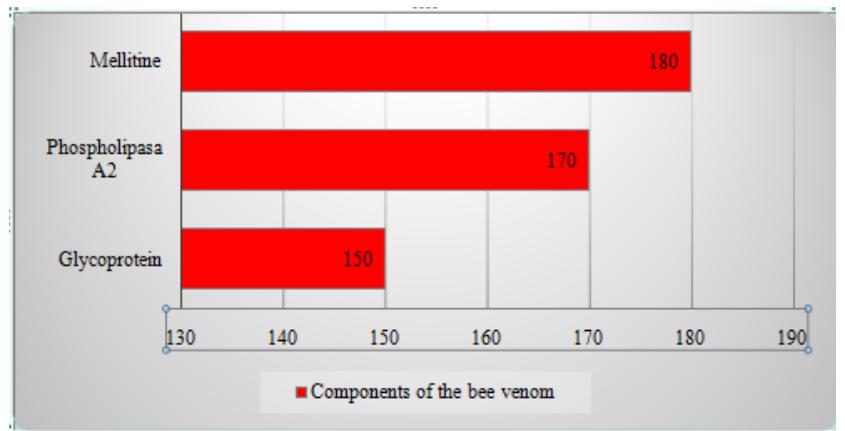

Figure 3 Diogramme of separation of bee venom components by gel chromatography on a column with Sephadex G-75.

\section{Conclusion}

i. A method of ion-exchange chromatography by stepwise elution with a concentration gradient from 0.01 to $1 \mathrm{M}$ sodium chloride solution on Servacel-52 column identified and identified three biologically active components of honey bee venom with molecular weights of 12,000, 14,600 and 22,000D.

ii. A polypeptide with $\mathrm{Mg} \sim 12000 \mathrm{D}$ is a toxic component identified as mellitine, a polypeptide with $\mathrm{Mg} \sim 14,600$ Is an enzyme of phospholipase A2, and a polypeptide with $\mathrm{Mg} 22000 \mathrm{D}$ is a glycoprotein.

\section{Acknowledgements}

None.

\section{Conflict of interest}

The authors declare(s) that there is no conflict of interest regarding the publication of this article.

\section{Referecnes}

1. Moon DO, Park SY, Lee KJ, et al. Bee venom and melittin reduce proinflammatory mediators in lipopolysaccharide-stimulated BV2 microglia. Int Immunopharmacol. 2007;7(8):1092-1101.

2. Maulet Y, Brodbeck U, Fulpius BW. Purification from bee venom of melittin devoid of phospholipase A2 contamination. Anal Biochem. 1982;127(1):61-67.

3. Vila Farres X, Giralt E, Vila J. Update of peptides with antibacterial activity. Curr Med Chem. 2012;19(36):6188-6198.

4. Wu R, Wang Q, Zheng Z, et al. Design, characterization and expression of a novel hybrid peptides melittin (1-13)-LL37 (17-30). Mol Biol Rep. 2014;41(7):4163-4169.

5. Stockwell VO, Duffy B. Use of antibiotics in plant agriculture. Rev Sci Tech. 2012;31(1):199-210.

6. Cichocka Jarosz E. Hymenoptera venom allergy in humans. Folia Med Cracov. 2012;52(3):43-60.

7. Moreno M, Giralt E. Three valuable peptides from bee and wasp venoms for therapeutic and biotechnological use:melittin, apamin and mastropan. Toxins (Basel). 2015;7(4):1126-1150.

8. http://www.allergen.org

9. Teoh AC, Ryu KH, Lee EG. Purification of Melittin Derived from Apis mellifera Bee Venom. Microbiol Biotechnol. 2017;27(1):84-91.

10. Ostroumova OS, Efimova SS, Malev VV, et al. Ionic channels in model lipid membranes. Russia: Russian Academy of Sciences Institute of Cytology RAS; 2012. 118 p.

11. Nishikawa H. Gangliosides inhibit bee venom melittin cytotoxicity but not phospholipase A2-induced degranulation in mast cells. Toxicology and Appl Pharmacol. 2011;252(3):228-236.

12. Protas AF, Bondareva OS, Muliavko NO. Purification and properties of bee venom protease. Biopolym Cell. 1999;15(4):292-296.

13. Barbara EC, Rudolf A, Shipolini. Chemistry and Pharmacology of Honey-bee Venom. UK; 2001. p. 329-415.

14. Piek T. Venoms of the Hymenoptera. Biochemical, Pharmacological and Behavioural Aspects. USA: Academic Press; 1986. 570 p.

15. Lariviere WR. The bee venom test: a new tonic-pain test. Pain. 1996;66(2-3):271-277.

16. Ali MA. Studies on bee venom and its medical uses. International Journal of Advancements in Research and Technology. 2012;1(2):6983. 